\title{
Marius Heemstra
}

\section{The Fiscus Judaicus and the Parting of the Ways}

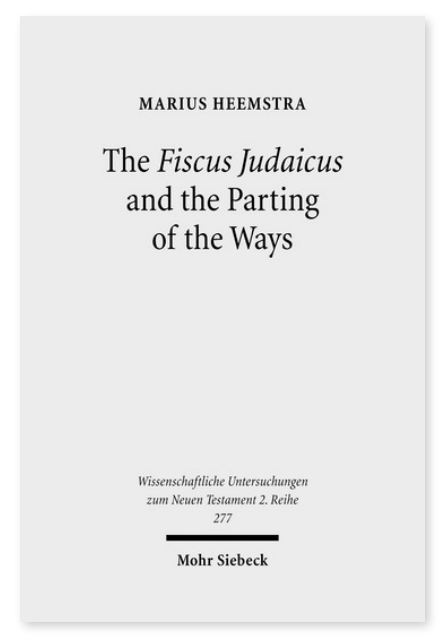

2010. XIII, 241 Seiten. WUNT II 277

ISBN 978-3-16-151620-7

DOI 10.1628/978-3-16-151620-7

eBook PDF $74,00 €$

ISBN 978-3-16-150383-2

fadengeheftete Broschur 74,00
[Der Fiscus Judaicus und die Trennung der Wege.]

Veröffentlicht auf Englisch.

Marius Heemstra zeigt auf, wie die strenge Regelung des Fiscus Judaicus unter dem römischen Kaiser Domitian (81-96) und die Reform dieses Fiscus unter Kaiser Nerva (96-98) die Trennung der Wege zwischen Judentum und Christentum beschleunigte, aus der sich dann schließlich zwei getrennte Religionen entwickelten.

Seit dem Jahr 96 verwendete die römische Obrigkeit eine strengere Definition des Begriffs »ude«, die es ihr erleichterte, zwischen Judentum (einer im Reich akzeptierten Religion) und Christentum (einer illegalen religiösen Bewegung) zu unterscheiden. Der Autor interpretiert diese Trennung als einen Bruch zwischen Judenchristen und Judentum. Beide Parteien beanspruchten für sich, die wahren Vertreter der Geschichte Israels zu sein. Marius Heemstra zieht für seine Argumentation den römischen und jüdischen Kontext der Johannesapokalypse, den Hebräerbrief und das Johannesevangelium heran und geht auch auf die Debatte um birkat ha-minim ein.

Marius Heemstra Born 1960; 1985 Masters Degree (Ancient History) from the University of Groningen; 2006 Masters Degree (Theology) from the University of Groningen; 2009 PhD from the University of Groningen; Insurance Manager for a multinational Dutch telecom operator.
Jetzt bestellen:

https://mohrsiebeck.com/buch/the-fiscus-judaicus-and-the-parting-of-the-ways-9783161516207?no_cache=1 order@mohrsiebeck.com

Telefon: +49 (0)7071-923-17

Telefax: +49 (0)7071-51104 